\title{
A randomized, double-blind, placebo-controlled, dose-ranging study using Genz-644470 and sevelamer carbonate in hyperphosphatemic chronic kidney disease patients on hemodialysis
}

\author{
This article was published in the following Dove Press journal: \\ International Journal of Nephrology and Renovascular Disease \\ 7 April 2014 \\ Number of times this article has been viewed
}

\author{
Moustafa Moustafa' \\ Lawrence Lehrner ${ }^{2}$ \\ Fahd Al-Saghir ${ }^{3}$ \\ Mark Smith ${ }^{4}$ \\ Sunita Goyal ${ }^{5}$ \\ Maureen Dillon ${ }^{5}$ \\ John Hunter ${ }^{5}$ \\ Randy Holmes-Farley ${ }^{5}$ \\ 'South Carolina Nephrology and \\ Hypertension Center Inc., Orangeburg, \\ SC, USA; ${ }^{2}$ Kidney Specialists of \\ Southern Nevada, Las Vegas, NV, USA; \\ ${ }^{3}$ Michigan Kidney Consultants, Pontiac, \\ MI, USA; ${ }^{4}$ Kidney Care Associates, LLC, \\ Augusta, GA, USA; ${ }^{5}$ Genzyme, a Sanofi \\ company, Cambridge, MA, USA
}

\begin{abstract}
Background: Genz-644470 is a new, nonabsorbed phosphate binding polymer. In an in vitro competitive phosphate binding assay, Genz- 644470 bound significantly more phosphate per gram than sevelamer. As a consequence, this clinical study evaluated the ability of Genz-644470 to lower serum phosphorus in patients on hemodialysis and compared serum phosphorus lowering of Genz-644470 with sevelamer carbonate and placebo. Because three different fixed doses of Genz-644470 and sevelamer carbonate were used, phosphate-lowering dose-responses of each agent were also analyzed.
\end{abstract}

Methods: A randomized, double-blind, dose-ranging study was conducted. After a 2-week phosphate binder washout, 349 hyperphosphatemic (serum phosphorus $>5.5 \mathrm{mg} / \mathrm{dL}$ ) hemodialysis patients were randomized to one of seven fixed-dose groups: placebo, Genz-644470 $2.4 \mathrm{~g} / \mathrm{day}$, Genz-644470 4.8 g/day, Genz-644470 7.2 g/day, sevelamer carbonate 2.4 g/day, sevelamer carbonate $4.8 \mathrm{~g}$ /day, or sevelamer carbonate $7.2 \mathrm{~g} /$ day. Indicated total daily doses were administered in fixed divided doses three times a day with meals for 3 weeks. The change in serum phosphorus during the treatment period and its dose-response patterns were assessed.

Results: Dose-dependent reductions in serum phosphorus were observed with both Genz-644470 and sevelamer carbonate. Serum phosphorus-lowering responses to fixed doses of sevelamer carbonate and Genz-644470 were enhanced in a roughly linear fashion with increasing doses over a threefold range after 3 weeks of treatment. Genz-644470 did not show any advantage in phosphorus lowering per gram of binder compared with sevelamer carbonate. Overall tolerability was similar between active treatment groups. The tolerability of sevelamer carbonate was consistent with prior studies and with the established safety profile of sevelamer.

Conclusion: Both Genz-644470 and sevelamer carbonate effectively lowered serum phosphate levels in a dose-dependent fashion in patients with chronic kidney disease on hemodialysis. However, Genz-644470 did not provide any advantage over sevelamer carbonate in phosphate lowering in vivo, as had been demonstrated in vitro.

Keywords: sevelamer carbonate, clinical trial, serum phosphorus, hemodialysis

\section{Introduction}

Sevelamer carbonate is a nonabsorbed, metal-free phosphate-binding polymer that effectively controls serum phosphorus levels in adherent patients with chronic kidney disease (CKD) ${ }^{1-3}$ Sevelamer is indicated in the United States and European Union for the control of hyperphosphatemia in dialysis patients; in Europe, it is also indicated for predialysis patients with serum phosphorus levels higher than $1.78 \mathrm{mmol} / \mathrm{L}$ (5.5 mg/dL). Nonadherence to phosphate binders, including sevelamer carbonate,
Correspondence: Moustafa Moustafa South Carolina Nephrology and Hypertension Center Inc., II 84 Orangeburg Mall Circle, Orangeburg, SC 29115, USA

$\mathrm{Tel}+|80353| 2220$

Fax + I 8035317553

Emailmamoustafa@hotmail.com 
is very common because of multiple factors, including dose frequency, resulting in a continued need for better phosphate control in the dialysis population., ${ }^{4,5}$

Sevelamer's in vitro phosphate binding capacity in noncompetitive tests markedly exceeds its in vivo phosphate binding capacity in animals, ${ }^{6}$ healthy volunteers in the firstin-humans sevelamer study, ${ }^{7}$ or patients with end-stage renal disease (ESRD). ${ }^{8}$ One hypothesis to explain this discordance is that noncompetitive in vitro assays have no organic anions present, whereas in the human gastrointestinal tract, organic anions (eg, bile acids and fatty acids) may diminish phosphate binding by competing for phosphate-binding sites. The search for more potent phosphate binding polymers to improve therapy of hyperphosphatemic dialysis patients thus requires better simulation of physiologic conditions. We developed an in vitro competitive phosphate binding assay in which binding of phosphate by sevelamer carbonate was greatly reduced to levels more in line with those observed clinically. ${ }^{7}$ Results from this assay were used to identify a new binder, Genz-644470, with potential for improved potency and reduced pill burden, which is evaluated in ESRD patients in the present study.

Genz-644470 is a structurally optimized new physical form of sevelamer carbonate that was designed to bind phosphate more selectively. The physical form comprises large aggregates of smaller particles that help deter the entry of large competing ions into the interior of the particles while allowing access by phosphate. Sevelamer carbonate and Genz-644470 showed an equivalent ability to bind phosphate in the noncompetitive binding assay without bile acids or fatty acids present. In the competitive phosphate binding assay, however, Genz-644470 bound 1.5 to 3 times as much phosphate in the anticipated, physiologically relevant binding time of 60-120 minutes compared with sevelamer carbonate (Figure 1; Sanofi, data on file, 2007). On the basis of these results, we hypothesized that the optimized binding characteristics of Genz-644470 would lead to an increase in potency compared with sevelamer carbonate with regard to lowering serum phosphorus levels in dialysis patients.

This clinical study evaluated the efficacy of three clinically relevant fixed doses of Genz-644470 and the same fixed doses of sevelamer carbonate compared with placebo in CKD patients on hemodialysis. The primary objective was to compare Genz-644470 with placebo with regard to efficacy in serum phosphorus reduction, safety, and tolerability. Secondary objectives compared Genz-644470 with sevelamer carbonate regarding efficacy in reducing serum phosphorus, serum lipids (total cholesterol and low-density lipoprotein [LDL]-cholesterol), and serum calcium-phosphorus product, as well as safety and tolerability. The dose-response relationships of each agent were also examined.

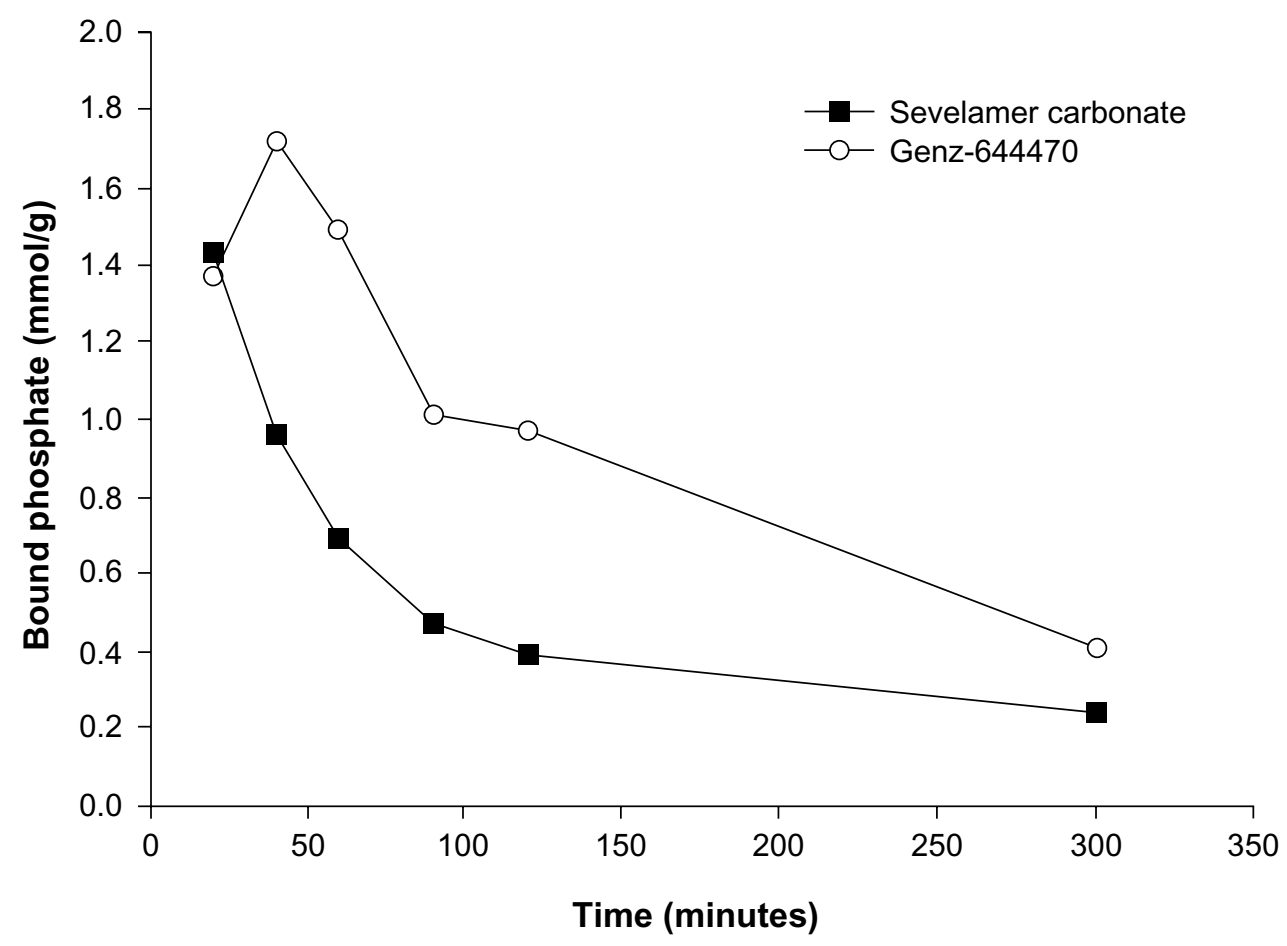

Figure I Competitive phosphate binding of sevelamer carbonate and Genz-644470 in vitro. 


\section{Methods}

\section{Patient selection}

Hemodialysis patients aged 18 years or older at 62 centers in the United States were enrolled in this study from February 11, 2009, to August 20, 2009. Patients were eligible for inclusion if they had been on hemodialysis three times per week for at least 3 months, were currently taking a phosphate binder, and had an intact parathyroid hormone (iPTH) $800 \mathrm{pg} / \mathrm{mL}$ or lower at screening and a serum phosphorus level higher than $5.5 \mathrm{mg} / \mathrm{dL}$ after a 2-week phosphate binder washout. Patients were excluded from the study if they had active dysphagia or swallowing disorder or a predisposition to, or current, bowel obstruction, ileus, or severe gastrointestinal motility disorders including severe constipation or any other clinically significant unstable medical condition.

The protocol and informed consent were reviewed and approved by the appropriate institutional review boards/ independent ethics committees. Schulman Associates IRB Inc. (Fort Lauderdale, FL, USA), provided ethics review and approval for the majority of sites. The Albert Einstein Healthcare Network institutional review board, Doylestown Hospital institutional review board, Indiana University-Purdue University Indianapolis/Clarian institutional review board, Lancaster General Hospital institutional review board, Medical College of Wisconsin Human Research Review Committee, Medical University of South Carolina Office of Research Integrity, University of Cincinnati institutional review board, and Washington University in St Louis Human Research Protection Office approved their investigators' participation. All patients provided written, informed consent before the initiation of any study-related activities. This research was carried out in accordance with good clinical practice guidelines, the Declaration of Helsinki, and applicable regulations. The study was registered with http://www.clinicaltrials.gov (NCT00853242).

\section{Study objectives}

The primary objectives were to test the hypothesis of superiority of Genz-644470 to placebo (both dosed three times daily with meals) in reducing serum phosphorus in hyperphosphatemic dialysis recipients and to compare the safety and tolerability of Genz-644470 with placebo. Secondary objectives were to compare Genz-644470 with placebo regarding the reduction of serum calcium-phosphorus product and serum lipids (total and LDL-cholesterol); to compare the relative potencies of Genz-644470 and sevelamer carbonate for reduction of serum phosphorus, serum lipids, and serum calcium-phosphorus product; and to compare the safety and tolerability of Genz-644470 with that of sevelamer carbonate.

The dose responses of both Genz-644470 and sevelamer carbonate were also examined to compare effects of the three fixed doses of each agent on serum phosphorus and LDL-cholesterol.

\section{Study design}

This was a multicenter, randomized, double-blind, doseranging study. After a 2-week phosphate binder washout, patients were randomized (stratified by serum phosphorus levels $\geq 7.0 \mathrm{mg} / \mathrm{dL}$ and $<7.0 \mathrm{mg} / \mathrm{dL}$ ) to one of seven fixeddose treatment groups: placebo tablets (three times a day with meals), Genz-644470 tablets $2.4 \mathrm{~g} /$ day ( $0.8 \mathrm{~g}$ three times a day with meals), Genz-644470 tablets $4.8 \mathrm{~g}$ /day (1.6 $\mathrm{g}$ three times a day with meals), Genz-644470 tablets $7.2 \mathrm{~g} /$ day ( $2.4 \mathrm{~g}$ three times a day with meals), Sevelamer carbonate tablets $2.4 \mathrm{~g}$ /day $(0.8 \mathrm{~g}$ three times a day with meals), Sevelamer carbonate tablets $4.8 \mathrm{~g} /$ day (1.6 g three times a day with meals), and Sevelamer carbonate tablets $7.2 \mathrm{~g} /$ day $(2.4 \mathrm{~g}$ three times a day with meals).

Patients continued into the treatment period and maintained this fixed dose for 3 weeks. During the treatment period, patients continued with their three times per week dialysis schedule. Samples for laboratory measurements were collected before dialysis. For patients on a MondayWednesday-Friday hemodialysis schedule, blood sampling took place on either a Wednesday or a Friday. For patients on a Tuesday-Thursday-Saturday schedule, blood sampling took place on either a Thursday or Saturday. Precedent exists for brief study designs (or per agent crossover treatment periods) of a few weeks in phosphate binder studies ${ }^{2,9}$ especially in Phase $\mathrm{II}^{10}$ or dose-ranging designs. In addition, the majority of the phosphate-binding effect by a given dose of sevelamer hydrochloride,,$^{11}$ sevelamer carbonate, ${ }^{2,12}$ and other agents ${ }^{13}$ has been observed to occur within 1 week, with a smaller, incremental effect observed at 2 weeks. A steady-state effect has been observed at 3 weeks, using lanthanum. ${ }^{14}$

\section{Efficacy and tolerability analyses}

The primary efficacy analysis was a comparison of the change in serum phosphorus from baseline to end of treatment or early termination (day 22/ET) between the Genz-644470 treatment groups and placebo, using Wilcoxon rank sum tests. Type 1 error rate was contained at $5 \%$ by using a sequential closed testing procedure.

Other efficacy analyses included a comparison of the change from baseline to day 22/ET between the Genz-644470 
treatment groups and placebo with regard to LDL-cholesterol, total cholesterol, and serum calcium (albumin-adjusted)phosphorus product. In addition, a comparison of the change from baseline, to day 22/ET between Genz-644470 and sevelamer carbonate at each dose was conducted with regard to serum phosphorus, LDL-cholesterol, total cholesterol, and serum calcium (albumin-adjusted)-phosphorus product. All of these efficacy parameters were compared using Wilcoxon rank sum tests. The sevelamer carbonate groups were used as an active control in this study, and the mean difference and 95\% confidence interval between sevelamer carbonate and placebo were reported for each dose level. Dose-response relationships within each agent were observed graphically and descriptively.

Percentage adherence to study drug and median treatment duration were summarized by treatment group. Percentage adherence was calculated as the number of tablets taken divided by the total number of tablets prescribed, multiplied by 100 . Tolerability was evaluated on the basis of adverse events (reported or observed) and changes in laboratory values. Corrected (albumin-adjusted) serum calcium and iPTH were measured as part of routine serum chemistry analysis.

The full analysis set (FAS) population included all patients with a baseline phosphorus measure and at least one postbaseline phosphorus measure 3 or fewer days after the date of the last study drug. Efficacy analyses were conducted using the FAS. Tolerability was assessed in all patients who received at least one dose of the randomized study drug (safety set).

The sample size was planned with respect to the primary efficacy parameter of the study, change from baseline to day $22 /$ ET in serum phosphorus. A total of 266 evaluable patients (38 patients per dose group) were required to achieve $80 \%$ power based on a two-group Student's $t$-test with a two-sided $5 \%$ type 1 error rate to detect a $1.00 \mathrm{mg} / \mathrm{dL}$ difference in change from baseline between placebo and Genz-644470, assuming a standard deviation of $1.52 \mathrm{mg} / \mathrm{dL}$. Approximately 315 patients (45 per dose group) were to be randomized to allow for withdrawals.

\section{Results}

\section{Patients}

Three hundred forty-nine hemodialysis patients were randomized in the study, and 93\% completed this study (Figure 2). Overall, the demographics and baseline characteristics of the patients were similar between treatment groups (Table 1).

\section{Medication adherence and treatment duration}

Treatment adherence was generally well balanced between treatment groups. During the randomized treatment period, mean percentage adherence in the safety set and the FAS

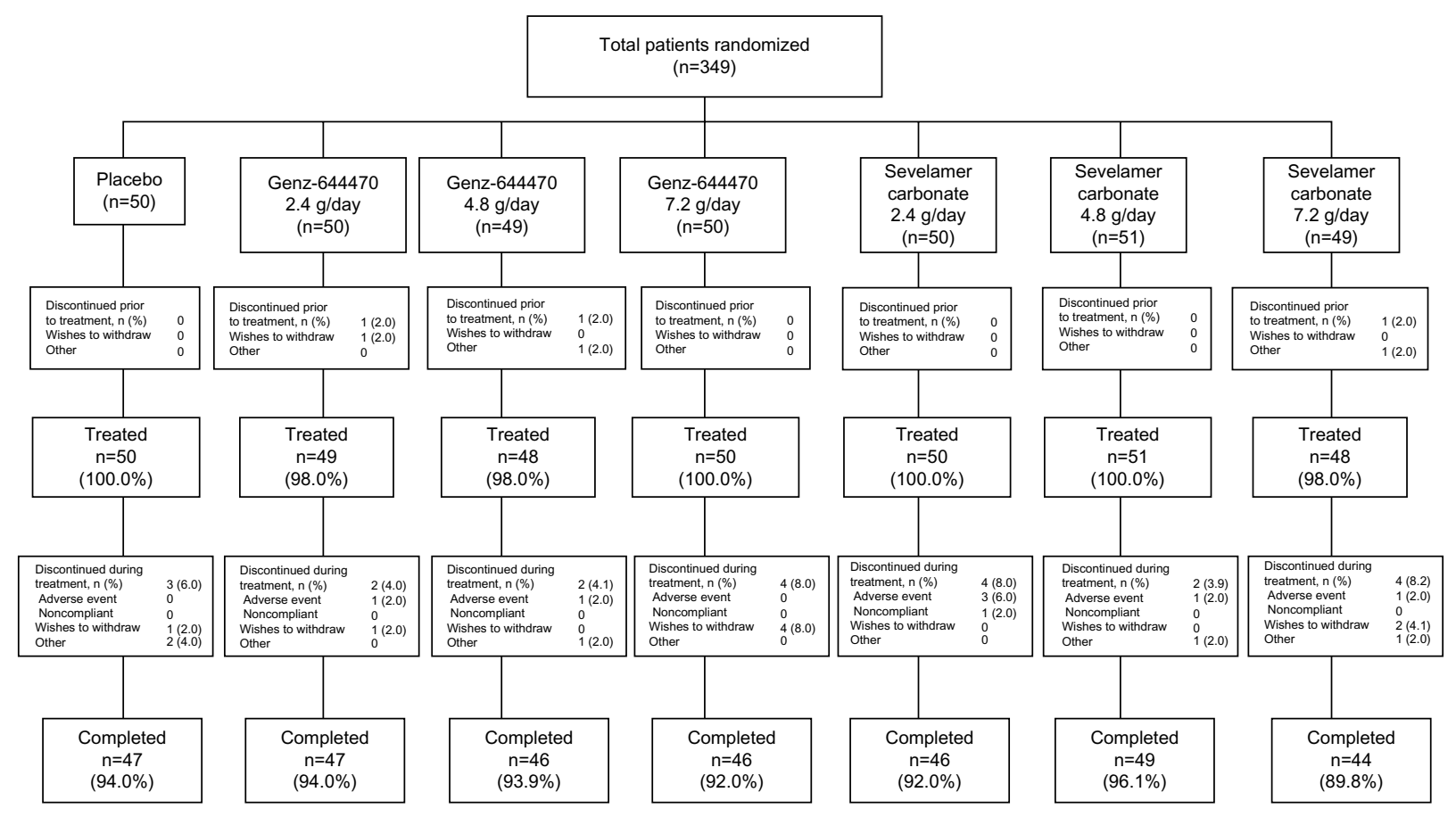

Figure 2 CONSORT diagram of patient disposition, all randomized patients. 
Table I Patient demographics and renal history, safety set

\begin{tabular}{|c|c|c|c|c|c|c|c|c|}
\hline & \multirow{2}{*}{$\begin{array}{l}\text { Placebo } \\
(\mathrm{N}=50)\end{array}$} & \multicolumn{3}{|c|}{ Genz-644470 } & \multicolumn{3}{|c|}{ Sevelamer carbonate } & \multirow{2}{*}{$\begin{array}{l}\text { Total } \\
(\mathrm{N}=346)\end{array}$} \\
\hline & & $\begin{array}{l}2.4 \text { g/day } \\
(\mathrm{N}=49)\end{array}$ & $\begin{array}{l}4.8 \mathrm{~g} / \mathrm{day} \\
(\mathrm{N}=48)\end{array}$ & $\begin{array}{l}7.2 \mathrm{~g} / \mathrm{day} \\
(\mathrm{N}=50)\end{array}$ & $\begin{array}{l}2.4 \text { g/day } \\
(\mathrm{N}=50)\end{array}$ & $\begin{array}{l}4.8 \mathrm{~g} / \mathrm{day} \\
(\mathrm{N}=5 \mathrm{I})\end{array}$ & $\begin{array}{l}7.2 \text { g/day } \\
(\mathrm{N}=48)\end{array}$ & \\
\hline \multicolumn{9}{|l|}{ Sex, n (\%) } \\
\hline Male & $30(60.0)$ & $25(51.0)$ & $25(52.1)$ & $31(62.0)$ & $28(56.0)$ & $30(58.8)$ & $33(68.8)$ & $202(58.4)$ \\
\hline Female & $20(40.0)$ & $24(49.0)$ & $23(47.9)$ & $19(38.0)$ & $22(44.0)$ & $21(4 \mid .2)$ & $15(3 \mid .3)$ & I $44(4 \mid .6)$ \\
\hline \multicolumn{9}{|l|}{ Race, n (\%) } \\
\hline Asian & 0 & $2(4.1)$ & $\mathrm{I}(2.1)$ & I (2.0) & $2(4.0)$ & 0 & $2(4.2)$ & $8(2.3)$ \\
\hline Black or African American & $21(42.0)$ & $20(40.8)$ & $25(52.1)$ & $25(50.0)$ & $23(46.0)$ & $25(49.0)$ & $22(45.8)$ & $|6|(46.5)$ \\
\hline White & $29(58.0)$ & $27(55.1)$ & $22(45.8)$ & $22(44.0)$ & $25(50.0)$ & $25(49.0)$ & $23(47.9)$ & $173(50.0)$ \\
\hline Other & 0 & 0 & 0 & $2(4.0)$ & 0 & I (2.0) & $\mathrm{I}(2.1)$ & $4(1.2)$ \\
\hline Age, years (mean $\pm S D$ ) & $59.1 \pm 13.6$ & $58.3 \pm 12.0$ & $54.7 \pm 11.3$ & $56.7 \pm 13.3$ & $54.6 \pm 13.4$ & $56.6 \pm 11.9$ & $53.6 \pm 13.1$ & $56.2 \pm 12.7$ \\
\hline \multicolumn{9}{|c|}{ Visit three, serum phosphorus group, n (\%) } \\
\hline$<7.0 \mathrm{mg} / \mathrm{dL}$ & $22(44.0)$ & $22(44.9)$ & $21(43.8)$ & $31(42.0)$ & $22(44.0)$ & $20(39.2)$ & $17(35.4)$ & $145(41.9)$ \\
\hline$\geq 7.0 \mathrm{mg} / \mathrm{dL}$ & $28(56.0)$ & $27(55.1)$ & $27(56.3)$ & $29(58.0)$ & $28(56.0)$ & $31(60.8)$ & $31(64.6)$ & $20 \mathrm{I}(58.1)$ \\
\hline \multicolumn{9}{|c|}{ Primary cause of chronic kidney disease, $n(\%)$} \\
\hline Hypertension & $19(38.0)$ & $17(34.7)$ & $15(3 \mid .3)$ & $22(44.0)$ & $17(34.0)$ & $13(25.5)$ & $14(29.2)$ & $117(33.8)$ \\
\hline Diabetes & $21(42.0)$ & $20(40.8)$ & $19(39.6)$ & $17(34.0)$ & $20(40.0)$ & $24(47.1)$ & $24(50.0)$ & $145(4 \mid .9)$ \\
\hline Other & $10(20.0)$ & $12(24.5)$ & $14(29.1)$ & II (22.0) & $13(26.0)$ & $14(27.4)$ & $10(20.8)$ & $84(24.3)$ \\
\hline Dialysis duration, years (mean $\pm \mathrm{SD}$ ) & $3.3 \pm 3.3$ & $3.3 \pm 3.7$ & $3.9 \pm 3.3$ & $4.6 \pm 4.1$ & $4.2 \pm 4.2$ & $4.0 \pm 3.6$ & $3.7 \pm 3.5$ & $3.9 \pm 3.7$ \\
\hline Diabetes history, n (\%) & $30(60.0)$ & $31(63.3)$ & $26(54.2)$ & $25(50.0)$ & $31(62.0)$ & $36(70.6)$ & $30(62.5)$ & $209(60.4)$ \\
\hline
\end{tabular}

Abbreviation: SD, standard deviation.

was $90 \%$. The median duration of treatment was 22.0 days for all groups.

\section{Efficacy}

Dose-dependent reductions in mean serum phosphorus from baseline to day 22/ET were seen with both Genz-644470 $(-0.58,-1.22$, and $-1.78 \mathrm{mg} / \mathrm{dL}$ for $2.4,4.8$, and $7.2 \mathrm{~g} / \mathrm{day}$, respectively) and sevelamer carbonate $(-0.89,-1.29$, and $-2.03 \mathrm{mg} / \mathrm{dL}$ for $2.4,4.8$, and $7.2 \mathrm{~g} /$ day, respectively); no change in serum phosphorus was seen in the placebo group (Figure 3). The change from baseline to day 22/ET in each Genz-644470 and sevelamer carbonate fixed-dose group was significant (all $P$-values $<0.05$ ). Placebo-adjusted mean differences ( $95 \%$ confidence interval) for change from baseline to day 22/ET in serum phosphorus in the 2.4, 4.8, and $7.2 \mathrm{~g}$ /day Genz-644470 groups, respectively, were -0.57 ( -1.13 to 0.00$),-1.21$ ( -1.80 to -0.61$)$, and $-1.76(-2.42$ to -1.10 ), and in the $2.4,4.8$, and $7.2 \mathrm{~g} /$ day sevelamer carbonate groups, they were -0.87 ( -1.49 to -0.25$),-1.27$ ( -1.92 to -0.63$)$, and -2.01 ( -2.56 to -1.46$)$, respectively. The mean decrease in serum phosphorus from baseline to day 22/ET was significantly greater for all three of the Genz-644470 dose groups compared with the placebo group (Wilcoxon rank sum tests, all $P$-values $<0.05$ ). The dose-response relationships of sevelamer carbonate and Genz-644470 for serum phosphate lowering at day 22 appeared roughly linear over the dose-range evaluated (Figure 3 ).
Serum phosphorus increased similarly for all treatment groups during the washout period (range of baseline values postwashout, $7.28-7.71 \mathrm{mg} / \mathrm{dL}$; of note, the $7.2 \mathrm{~g} /$ day groups for both agents had slightly higher baseline phosphorus than the other dose groups or placebo group). Serum phosphorus reduction was greatest during the first week of active treatment and reached a plateau value by the second or third week of measurements. The dose-response curves over time for sevelamer carbonate and Genz-644470 were almost symmetrical, with comparable reductions in serum phosphorus at each point for each fixed dose. Change from baseline in serum phosphorus is presented by treatment group in Figure 4. Serum phosphate was rapidly lowered between baseline and day 8; maximal phosphate lowering occurred by day 15 for the highest dose of each agent and by day 22 for all dose groups.

Each dose of Genz-644470 and the 4.8 and $7.2 \mathrm{~g} /$ day doses of sevelamer carbonate significantly reduced LDLcholesterol from baseline to day 22/ET (all Genz-644470 $P$-values $<0.05 ; 95 \%$ confidence interval for 4.8 and $7.2 \mathrm{~g}$ /day doses of sevelamer carbonate did not cross zero). Placebo-adjusted mean differences ( $95 \%$ confidence interval) in change from baseline to day 22/ET in LDL-cholesterol were $-14.1 \mathrm{mg} / \mathrm{dL}(-21.8$ to -6.4$),-11.9 \mathrm{mg} / \mathrm{dL}(-19.5$ to -4.3 ), and $-20.6 \mathrm{mg} / \mathrm{dL}(-29.3$ to -11.9$)$ in the $2.4,4.8$, and $7.2 \mathrm{~g} /$ day Genz-644470 groups, respectively, and $-6.2 \mathrm{mg} / \mathrm{dL}$ $(-12.6$ to 0.2$),-16.4 \mathrm{mg} / \mathrm{dL}$ ( -23.2 to -9.6$)$, and $-21.3 \mathrm{mg} / \mathrm{dL}$ 


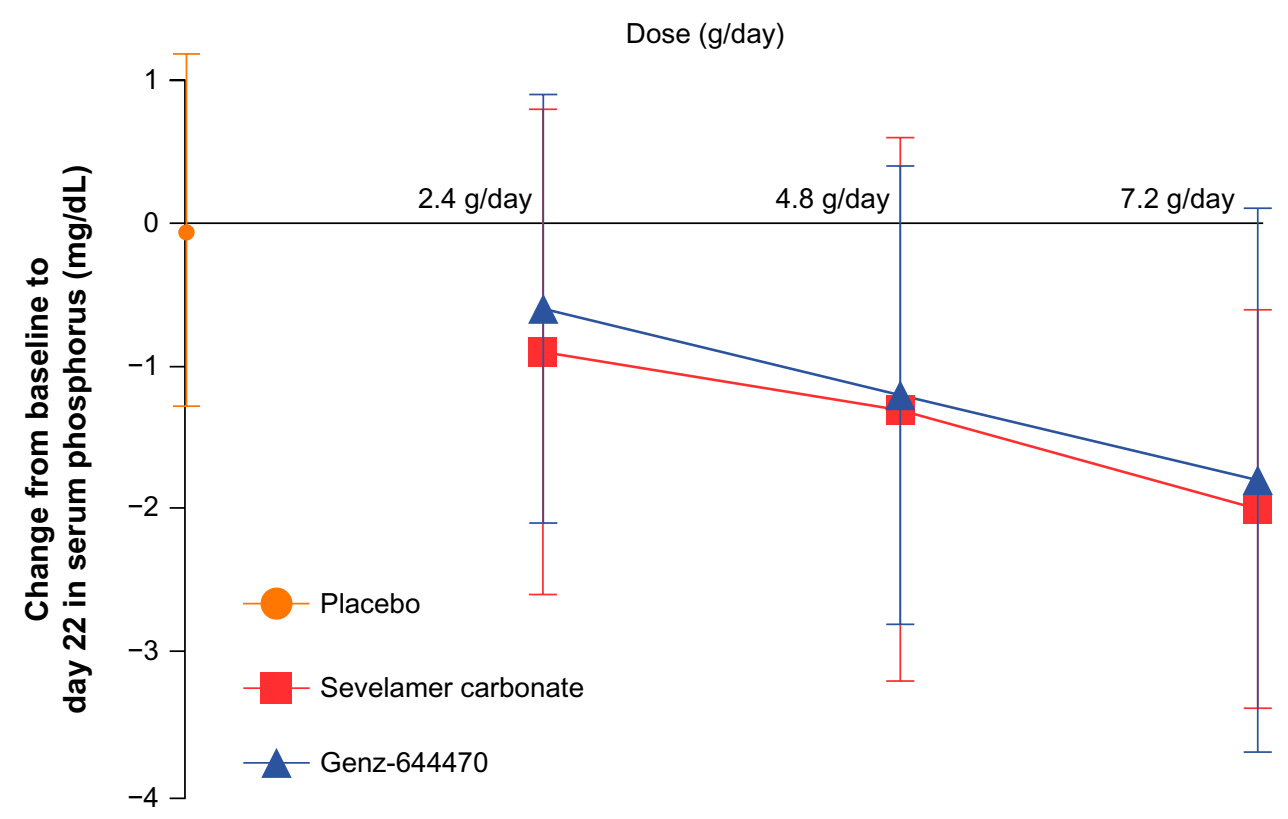

Figure 3 Mean ( \pm standard deviation) change in serum phosphorus from baseline to end of treatment (day 22). Note: Data for the placebo group are presented for comparison purposes.

A

Postbaseline

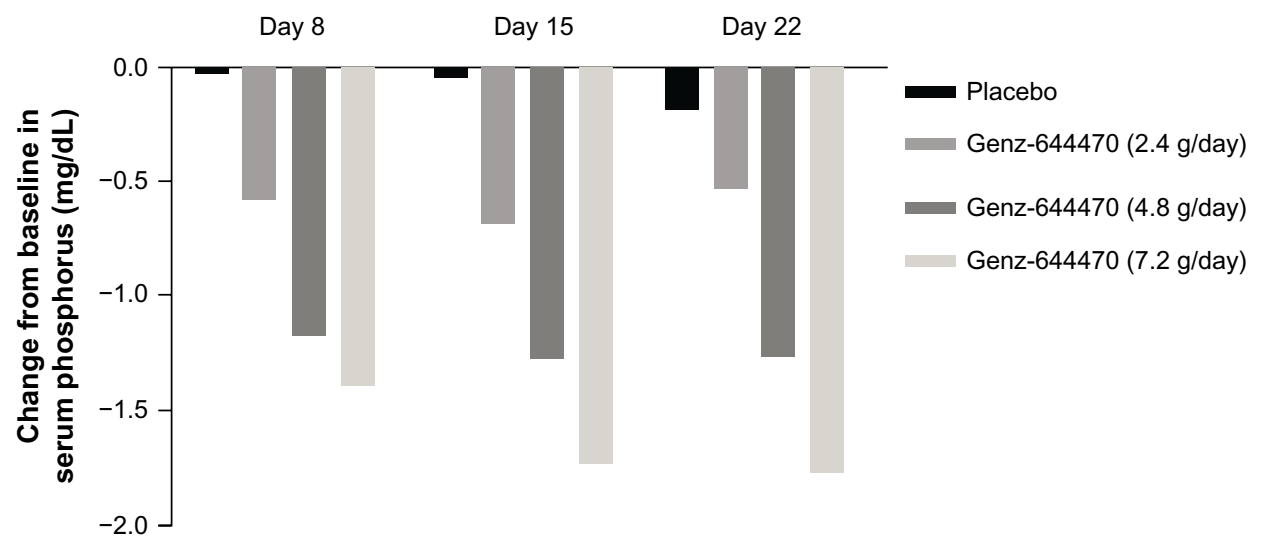

B

Postbaseline

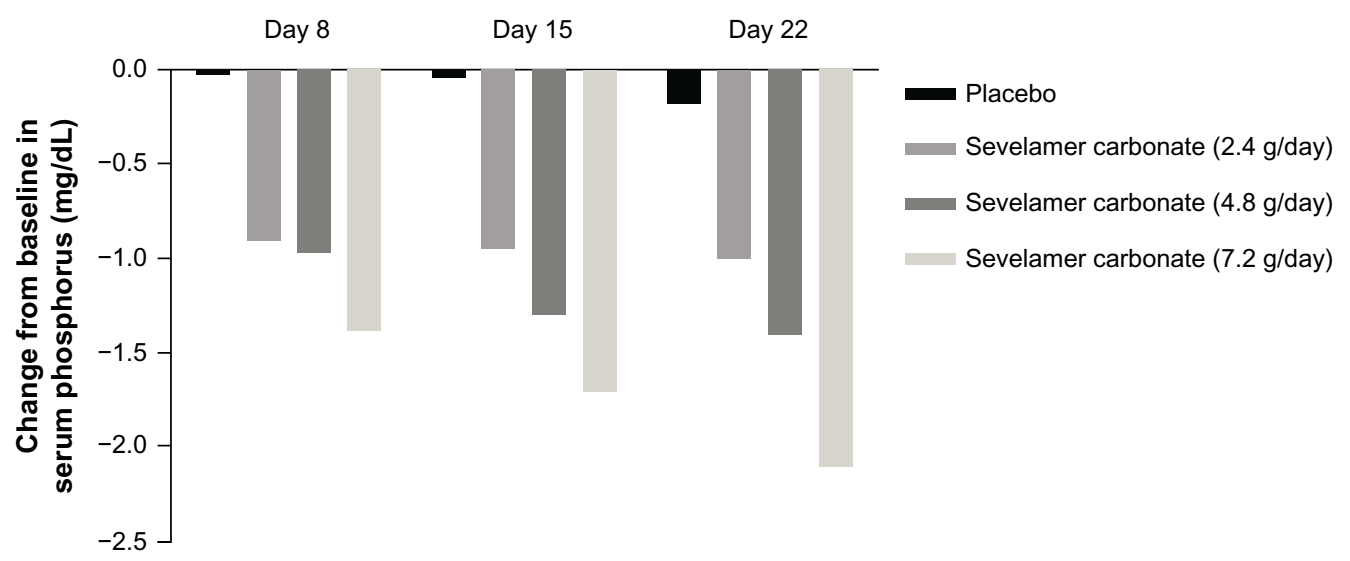

Figure 4 Changes from baseline in serum phosphorus at each visit following treatment with Genz-644470 (A) and sevelamer (B). 
$(-30.1$ to -12.4$)$ in the $2.4,4.8$, and $7.2 \mathrm{~g}$ /day sevelamer carbonate groups, respectively (Table 2 ).

The mean decrease in LDL-cholesterol from baseline to day 22/ET was significantly greater for all three of the Genz-644470 dose groups compared with the placebo group (all $P$-values $<0.05$ ). Genz-644470 did not show a significant improvement in LDL-cholesterol lowering compared with sevelamer carbonate at any dose (Table 2).

Dose-dependent and significant percentage reductions in LDL-cholesterol (95\% confidence interval) were seen with sevelamer carbonate $(-8 \%[-14.54$ to -1.26$],-21 \%[-26.88$ to -15.86$]$ and $-27 \%$ [ -34.68 to -20.05$]$ from baseline values of 72,76 , and $85 \mathrm{mg} / \mathrm{dL}$ for $2.4,4.8$, and $7.2 \mathrm{~g} /$ day, respectively). LDL-cholesterol reductions with Genz-644470 were also statistically significant but showed less consistent dose-dependence ( $-17 \%$ [ -23.53 to -11.37$],-14 \%$ [ -21.63 to -6.98$],-24 \%$ [-33.21 to -15.03$]$ from baseline values of 86,84 , and $83 \mathrm{mg} / \mathrm{dL}$ for 2.4, 4.8, and $7.2 \mathrm{~g}$ /day, respectively; Table 2).

No clinically meaningful or dose-dependent changes occurred from baseline to day 22/ET in corrected (albuminadjusted) serum calcium within or between the Genz-644470 or sevelamer groups. Serum iPTH did decrease from baseline to day 22/ET, as expected, in both treatment groups at each dose, with greater decreases seen at higher doses (Table 3).

Results for total cholesterol and serum calcium (albuminadjusted)-phosphorus product were similar to the LDLcholesterol and serum phosphorus results, respectively (data not shown).

\section{Tolerability}

Overall tolerability was similar among the active treatment groups. Table 4 presents the treatment-related adverse events occurring in three or more patients. All treatment-related adverse events were assessed as nonserious and mild or moderate in intensity.

There were no clinically meaningful mean changes in the safety laboratory parameters or vital signs during the study between the treatment groups.

\section{Discussion}

The purpose of this clinical study was to evaluate the phosphate-binding potential of a novel phosphate-binding polymer and its ability to lower serum phosphorus in patients with CKD on hemodialysis. Genz-644470 had been developed with the goal of being a nonabsorbed, metal-free phosphate binder that was at least as safe as and more potent than sevelamer carbonate.

In vitro competitive phosphate binding assays suggested that Genz-644470 was an effective phosphate binder and was more potent, on a gram per gram basis, compared with sevelamer carbonate. This clinical trial did demonstrate that Genz-644470 effectively lowered serum phosphorus levels in hyperphosphatemic CKD patients on hemodialysis. However, the phosphate-lowering activity of Genz-644470 was not superior to sevelamer carbonate.

Several factors may have contributed to the discrepancy between the in vitro and in vivo phosphate-binding efficacy of Genz-644470 compared with that of sevelamer carbonate. In vitro studies provide a very simplified model to predict binding kinetics that may be seen in the complex and changing composition of the human gastrointestinal tract. For example, factors that may have influenced the translation of in vitro results to in vivo correlates include time-dependent changes of organic anion composition, fluid and electrolyte composition,

Table 2 Low-density lipoprotein cholesterol $(\mathrm{mg} / \mathrm{dL}$ ) change from baseline to day 22 (end of treatment)

\begin{tabular}{|c|c|c|c|c|c|c|c|}
\hline \multirow{2}{*}{$\begin{array}{l}\text { Low-density lipoprotein } \\
\text { cholesterol (mg/dL) }\end{array}$} & \multirow{2}{*}{$\begin{array}{l}\text { Placebo } \\
(\mathrm{N}=50)\end{array}$} & \multicolumn{3}{|l|}{ Genz-644470 } & \multicolumn{3}{|c|}{ Sevelamer carbonate } \\
\hline & & $\begin{array}{l}2.4 \text { g/day } \\
(\mathrm{N}=48)\end{array}$ & $\begin{array}{l}4.8 \text { g/day } \\
(N=47)\end{array}$ & $\begin{array}{l}7.2 \text { g/day } \\
(\mathrm{N}=46)\end{array}$ & $\begin{array}{l}2.4 \text { g/day } \\
(\mathrm{N}=49)\end{array}$ & $\begin{array}{l}4.8 \text { g/day } \\
(N=48)\end{array}$ & $\begin{array}{l}7.2 \text { g/day } \\
(\mathrm{N}=47)\end{array}$ \\
\hline Baseline, mean (SD) & $85.3(36.1)$ & $86.1(34.6)$ & $84.4(33.8)$ & $83.8(33.7)$ & $71.5(21.8)$ & $75.5(27.5)$ & $84.9(30.9)$ \\
\hline Day 22/ET, mean (SD) & $84.0(36.3)$ & $70.7(32.5)$ & $71.3(34.9)$ & $61.3(29.6)$ & $62.3(17.8)$ & $58.8(23.7)$ & $62.1(33.1)$ \\
\hline $\begin{array}{l}\text { Change from baseline } \\
\text { to day } 22 / E T \text {, mean (SD) }\end{array}$ & $-1.3(17.4)$ & $-15.4(19.8)$ & $-13.2(18.6)$ & $-21.9(23.5)$ & $-7.5(13.0)$ & $-17.7(\mid 4.8)$ & $-22.6(24.5)$ \\
\hline Wilcoxon signed rank $P$-value & 0.4472 & $<0.000$ I & $<0.0001$ & $<0.0001$ & 0.0003 & $<0.0001$ & $<0.0001$ \\
\hline $\begin{array}{l}\text { Mean placebo-adjusted } \\
\text { difference }(95 \% \mathrm{Cl})\end{array}$ & - & $\begin{array}{l}-\mid 4.1,(-2 \mid .8 \\
\text { to }-6.4)^{*}\end{array}$ & $\begin{array}{l}-11.9,(-19.5 \\
\text { to }-4.3)^{*}\end{array}$ & $\begin{array}{l}-20.6,(-29.3 \\
\text { to }-11.9)^{*}\end{array}$ & $\begin{array}{l}-6.2,(-12.6 \\
\text { to } 0.2)^{\#}\end{array}$ & $\begin{array}{l}-16.4,(-23.2 \\
\text { to }-9.6)^{\#}\end{array}$ & $\begin{array}{l}-21.3,(-30.1 \\
\text { to }-12.4)^{\#}\end{array}$ \\
\hline $\begin{array}{l}\text { Mean percentage change } \\
\text { from baseline to day } 22 / \mathrm{ET} \\
(\mathrm{SD}),(95 \% \mathrm{Cl})\end{array}$ & $\begin{array}{l}-0.5(24.7) \\
(-7.87 \\
\text { to } 6.98)\end{array}$ & $\begin{array}{l}-17.5(20.7) \\
(-23.53 \\
\text { to }-11.37)\end{array}$ & $\begin{array}{l}-14.3(23.8) \\
(-21.63 \\
\text { to }-6.98)\end{array}$ & $\begin{array}{l}-24.1(29.9) \\
(-33.21 \\
\text { to }-15.03)\end{array}$ & $\begin{array}{l}-7.9(22.1) \\
(-14.54 \\
\text { to }-1.26)\end{array}$ & $\begin{array}{l}-21.4(18.4) \\
(-26.88 \\
\text { to }-15.86)\end{array}$ & $\begin{array}{l}-27.4(24.6) \\
(-34.68 \\
\text { to }-20.05)\end{array}$ \\
\hline
\end{tabular}

Notes: $95 \% \mathrm{Cl}$ showed significant differences between sevelamer and placebo for the 4.8 and $7.2 \mathrm{~g} /$ day doses, although $P$-values were not formally developed. $* P<0.05$ Genz-644470 versus placebo; \#differences between Genz-644470 versus sevelamer carbonate were nonsignificant.

Abbreviations: ET, end of treatment or early termination; SD, standard deviation; $\mathrm{Cl}$, confidence interval. 


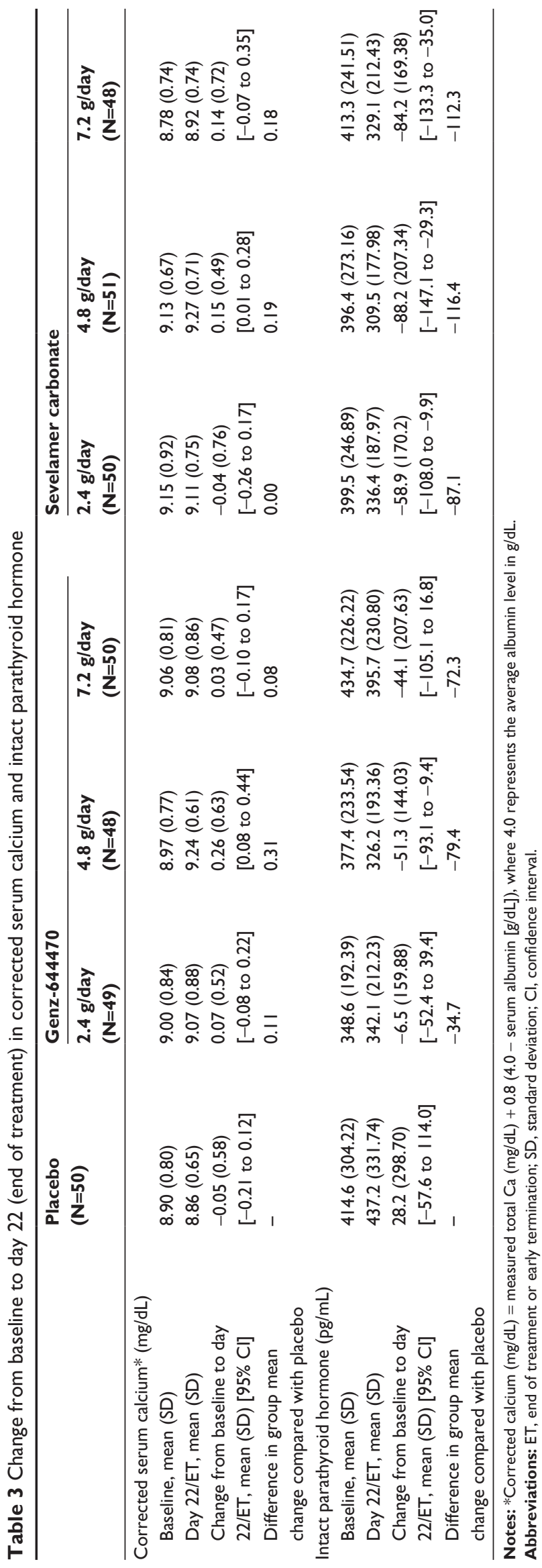

changing gastrointestinal tract $\mathrm{pH}$, and mechanical factors. The assumption of binding time also may have affected the predictability of the in vitro assay. Given small intestine transit and reabsorption times, it was believed that phosphate binding took place about 60-120 minutes after exposure to small intestinal tract contents. For this reason, phosphate binding at 60-120 minutes was selected for the key time in assessing phosphate binding in the competitive assay. If the actual binding time in vivo was significantly shorter than 60 minutes, the relative potency of Genz-644470 compared with sevelamer carbonate is predicted to have approached unity.

Studies in rats were conducted to further examine the phosphate-binding properties of Genz- 644470 before conducting a clinical trial but were believed to be unreliable in predicting the relative potency of phosphate binders because of the time-dependent nature of phosphate binding and known differences in gastrointestinal transit times, between rats and people.

This is the first fixed-dose study of sevelamer carbonate and, thus, provides useful data regarding its effect on parameters of interest, weekly during a 3-week period. In contrast, the majority of studies investigating the efficacy and safety of phosphate binders have used dose titration to achieve optimal phosphorus lowering. Also novel is this study's evaluation of the efficacy and safety of Genz-644470 in vivo in hemodialysis patients, which unexpectedly showed less difference from sevelamer carbonate than predicted from in vitro comparisons. The physiologic environment of the gastrointestinal tract is likely to influence phosphate binding capacity in vivo in contrast to in vitro studies.

In this study, the clinical benefit/risk profile of Genz644470 was not found to be superior to that seen with sevelamer carbonate. However, this study adds to the knowledge base regarding the dose-response effect of sevelamer carbonate, which is of clinical interest. Previous explicit studies on sevelamer dose-response have generally used sevelamer hydrochloride, the first commercially available form of sevelamer, and have observed that the extent of serum phosphorus lowering and/or fecal phosphorus excretion is enhanced with increasing doses of sevelamer hydrochloride in rats ${ }^{6}$ or healthy human volunteers. ${ }^{7}$ A subsequent dose-titration study in ESRD patients showed that the dose required to maintain serum phosphorus within goal varied with patients' dietary phosphate intake. ${ }^{8}$ Previous studies in ESRD patients have established the equivalence of sevelamer carbonate tablets to sevelamer hydrochloride tablets with thrice-daily dosing $^{1}$ and the ability of once-daily dosing of sevelamer carbonate powder for oral suspension to decrease serum 
Table 4 Treatment-related adverse events occurring in three or more patients

\begin{tabular}{|c|c|c|c|c|c|c|c|}
\hline \multirow[t]{2}{*}{ Adverse event } & \multirow{2}{*}{$\begin{array}{l}\text { Placebo } \\
(\mathrm{N}=50) \\
n(\%)\end{array}$} & \multicolumn{3}{|l|}{ Genz-644470 } & \multicolumn{3}{|c|}{ Sevelamer carbonate } \\
\hline & & $\begin{array}{l}2.4 \text { g/day } \\
(\mathrm{N}=49), \text { n (\%) }\end{array}$ & $\begin{array}{l}4.8 \text { g/day } \\
(\mathrm{N}=48), \mathrm{n}(\%)\end{array}$ & $\begin{array}{l}7.2 \text { g/day } \\
(\mathrm{N}=50), \mathrm{n}(\%)\end{array}$ & $\begin{array}{l}2.4 \text { g/day } \\
(\mathrm{N}=50), \mathrm{n}(\%)\end{array}$ & $\begin{array}{l}4.8 \text { g/day } \\
(\mathrm{N}=5 \mathrm{I}), \mathrm{n}(\%)\end{array}$ & $\begin{array}{l}7.2 \text { g/day } \\
(\mathrm{N}=48), \mathrm{n}(\%)\end{array}$ \\
\hline Any adverse event & $2(4.0)$ & $5(10.2)$ & $3(6.3)$ & $9(18.0)$ & $7(14.0)$ & $3(5.9)$ & $8(16.7)$ \\
\hline Gastrointestinal disorders & $0(0)$ & $3(6.1)$ & I (2.I) & $6(12.0)$ & $5(10.0)$ & $2(3.9)$ & $5(10.4)$ \\
\hline Nausea & $0(0)$ & $0(0)$ & I (2.I) & I (2.0) & $2(4.0)$ & I (2.0) & $3(6.3)$ \\
\hline Diarrhea & $0(0)$ & I (2.0) & $0(0)$ & $2(4.0)$ & I (2.0) & I (2.0) & $2(4.2)$ \\
\hline Constipation & $0(0)$ & $\mathrm{I}(2.0)$ & $0(0)$ & $\mathrm{I}(2.0)$ & $2(4.0)$ & $\mathrm{I}(2.0)$ & $0(0)$ \\
\hline Dyspepsia & $0(0)$ & I (2.0) & $0(0)$ & I (2.0) & $0(0)$ & $0(0)$ & $I(2 . I)$ \\
\hline Vomiting & $0(0)$ & $0(0)$ & $\mathrm{I}(2.1)$ & $0(0)$ & $I(2.0)$ & $0(0)$ & $I(2 . I)$ \\
\hline $\begin{array}{l}\text { Metabolism and nutrition } \\
\text { disorders }\end{array}$ & $2(4.0)$ & $0(0)$ & $0(0)$ & $0(0)$ & $2(4.0)$ & I (2.0) & $4(8.3)$ \\
\hline Hyperphosphatemia & I (2.0) & $0(0)$ & $0(0)$ & $0(0)$ & $I(2.0)$ & I (2.0) & $I(2.1)$ \\
\hline $\begin{array}{l}\text { Skin and subcutaneous } \\
\text { tissue disorders }\end{array}$ & $0(0)$ & $2(4.1)$ & $0(0)$ & $2(4.0)$ & I (2.0) & $0(0)$ & $I(2.1)$ \\
\hline Pruritus & $0(0)$ & I (2.0) & $0(0)$ & $2(4.0)$ & I (2.0) & $0(0)$ & I (2.I) \\
\hline
\end{tabular}

phosphate significantly. ${ }^{12}$ A recent Chinese study showed that dose-titration of sevelamer carbonate in patients with ESRD was well-tolerated, safe, and effective in reducing serum phosphorus over the course of 57 days of treatment. ${ }^{15}$

The fixed-dose design of the present study allowed evaluation of the dose-response of both phosphate binders. Dose-dependent reductions in serum phosphorus were observed with greater decreases seen at higher doses of sevelamer carbonate. This study also allowed observation of the early time course of phosphorus reduction over 22 days of treatment. The vast majority of total serum phosphorus reduction per fixed dose occurred during the first week of active treatment. Previous studies of sevelamer have shown significant phosphate lowering within 1 week with small, incremental lowering at 2 weeks. ${ }^{2,11,12}$ Therefore, the 3-week observation period employed in this study was considered of sufficient duration for an initial comparison of the efficacy of Genz-644470 and sevelamer carbonate in hemodialysis patients.

The tolerability of sevelamer carbonate was consistent with prior studies and the established safety profile of sevelamer. ${ }^{2,3}$

In summary, both Genz-644470 and sevelamer carbonate effectively lowered hemodialysis patients' serum phosphorus levels in a dose-dependent fashion, but Genz-644470 did not show an advantage in phosphorus lowering in dialysis patients compared with sevelamer carbonate, as had been demonstrated by an in vitro assay. ${ }^{6-8}$

\section{Author contributions}

$\mathrm{MM}$, contributing study investigator, contributed to multiple iterations of the manuscript text. LL, FA-S, and MS are contributing study investigators. RH-F is the coinventor of
Genz-644470 and designed the in vitro studies. MD is the senior director of clinical research supporting study design, data analysis, and interpretation. $\mathrm{JH}$ is the study statistician and supported study design, analysis, and interpretation. SG is the study medical director and supported study design, analysis, and interpretation. All authors revised the manuscript for important intellectual content and approved the final submitted version. Principal investigators (additional to the authors) and participating sites are detailed in Supplementary Table 1.

\section{Acknowledgments}

This study was supported by Genzyme, a Sanofi company. The authors acknowledge the editorial assistance of Stuart Murray, MSc, CMPP, from Envision Scientific Solutions, which was contracted by Sanofi to provide publication support services.

\section{Disclosure}

Maureen Dillon is an employee of Sanofi, formerly known as Genzyme. Sunita Goyal, Randy Holmes-Farley, and John Hunter were employed at Genzyme when the study was performed. Moustafa Moustafa, Lawrence Lehrner, Fahd Al-Saghir, and Mark Smith have received research funding from Sanofi, formerly Genzyme. The authors have no other conflicts of interest in this work.

\section{References}

1. Delmez J, Block G, Robertson J, et al. A randomized, double-blind, crossover design study of sevelamer hydrochloride and sevelamer carbonate in patients on hemodialysis. Clin Nephrol. 2007;68(6):386-391.

2. Fan S, Ross C, Mitra S, et al. A randomized, crossover design study of sevelamer carbonate powder and sevelamer hydrochloride tablets in chronic kidney disease patients on haemodialysis. Nephrol Dial Transplant. 2009;24(12):3794-3799. 
3. Ketteler M, Rix M, Fan S, et al. Efficacy and tolerability of sevelamer carbonate in hyperphosphatemic patients who have chronic kidney disease and are not on dialysis. Clin J Am Soc Nephrol. 2008;3(4): 1125-1130.

4. Young EW, Albert JM, Satayathum S, et al. Predictors and consequences of altered mineral metabolism: the Dialysis Outcomes and Practice Patterns Study. Kidney Int. 2005;67(3):1179-1187.

5. Tomasello S, Dhupar S, Sherman RA. Phosphate binders, K/DOQI guidelines, and compliance: the unfortunate reality. Dial Transplant. 2004;33(5):236-242.

6. Rosenbaum DP, Holmes-Farley SR, Mandeville WH, Pitruzzello M, Goldberg DI. Effect of RenaGel, a non-absorbable, cross-linked, polymeric phosphate binder, on urinary phosphorus excretion in rats. Nephrol Dial Transplant. 1997;12(5):961-964.

7. Burke SK, Slatopolsky EA, Goldberg DI. RenaGel, a novel calciumand aluminium-free phosphate binder, inhibits phosphate absorption in normal volunteers. Nephrol Dial Transplant. 1997;12(8):1640-1644.

8. Goldberg DI, Dillon MA, Slatopolsky EA, et al. Effect of RenaGel, a non-absorbed, calcium- and aluminium-free phosphate binder, on serum phosphorus, calcium, and intact parathyroid hormone in end-stage renal disease patients. Nephrol Dial Transplant. 1998;13(9):2303-2310.

9. Sprague SM, Ross EA, Nath SD, Zhang P, Pratt RD, Krause R. Lanthanum carbonate vs sevelamer hydrochloride for the reduction of serum phosphorus in hemodialysis patients: a crossover study. Clin Nephrol. 2009;72(4):252-258.
10. Finn WF, Joy MS, Hladik GA; Lanthanum Study Group. Results of a randomized dose-ranging, placebo controlled study of lanthanum carbonate for reduction of serum phosphate in chronic renal failure patients receiving hemodialysis. J Am Soc Nephrol. 1999;10:261A.

11. Chertow GM, Burke SK, Lazarus JM, et al. Poly[allylamine hydrochloride] (RenaGel): a noncalcemic phosphate binder for the treatment of hyperphosphatemia in chronic renal failure. Am J Kidney Dis. 1997;29(1):66-71.

12. Fishbane S, Delmez J, Suki WN, et al. A randomized, parallel, openlabel study to compare once-daily sevelamer carbonate powder dosing with thrice-daily sevelamer hydrochloride tablet dosing in CKD patients on hemodialysis. Am J Kidney Dis. 2010;55(2):307-315.

13. Hutchison AJ. Improving phosphate-binder therapy as a way forward. Nephrol Dial Transplant. 2004;19(1):i19-i24.

14. Finn WF, Joy MS, Hladik G; Lanthanum Study Group. Efficacy and safety of lanthanum carbonate for reduction of serum phosphorus in patients with chronic renal failure receiving hemodialysis. Clin Nephrol. 2004;62(3):193-201.

15. Chen N, Wu X, Ding X, et al. Sevelamer carbonate lowers serum phosphorus effectively in haemodialysis patients: a randomized, double-blind, placebo-controlled, dose-titration study. Nephrol Dial Transplant. 2014;29(1):152-160. 


\section{Supplementary material}

Table SI Principal investigators and participating sites

\begin{tabular}{|c|c|}
\hline Investigators & US Institutions \\
\hline Sharon Moe, MD & Indiana University, Indianapolis, IN \\
\hline Samuel Blumenthal, MD & Medical College of Wisconsin, Milwaukee, WI \\
\hline Steven Zeig, MD & Pines Clinical Research, Inc., Pembroke Pines, FL \\
\hline Mark Kaplan, MD & Nephrology Associates, PC, Nashville, TN \\
\hline Riad Darwish, MD & American Institute of Research, Whittier, CA \\
\hline Joseph Lee, MD & Apex Research of Riverside, Riverside, CA \\
\hline Rasib Raja, MD & Albert Einstein Medical Center, Philadelphia, PA \\
\hline Adegbenga Adetola, MD & American Institute of Research, Whittier, CA \\
\hline Aamir Jamal, MD & North America Research Institute, San Dimas, CA \\
\hline Mohammad Ismail, MD & Mohammad Ismail MD, Inc., Paramount, CA \\
\hline Fahd Al-Saghir, MD & Michigan Kidney Consultants, Pontiac, MI \\
\hline James Delmez, MD & Washington University School of Medicine, Chromalloy American Kidney Center, St Louis, MO \\
\hline Ajay Gupta, MD & American Institute of Research, Whittier, CA \\
\hline Nicholas Krivenko, MD & Arkansas Nephrology Services, Ltd, Hot Springs, AR \\
\hline Edward Himot, MD & Georgia Kidney Associates, Inc., Marietta, GA \\
\hline Warren Shapiro, MD & Kidney Care Associates, PLLC, Brooklyn, NY \\
\hline Lionel Mailloux, MD & Long Island Hypertension and Nephrology, PLLC, Port Washington, NY \\
\hline Nirupama Vemuri, MD & Sierra View Nephrology, SC, Porterville, CA \\
\hline Mark Smith, MD & Kidney Care Associates, LLC, Augusta, GA \\
\hline Peter McCauley, MD & National Institute of Clinical Research, Bakersfield, CA \\
\hline Suresh Kamath, MD & University of Cincinnati College of Medicine, Cincinnati, $\mathrm{OH}$ \\
\hline Jay Ocuin, MD & Dupont III, PC, Washington, DC \\
\hline Freemu Varghese, MD & Diagnostic Clinic of Houston, Houston, TX \\
\hline Jose Cangiano-Rivera, MD & Jose L Cangiano-Rivera, MD, San Juan, PR \\
\hline G Edward Newman, MD & G Edward Newman, MD, PLLC, Knoxville, TN \\
\hline Ambrose Tsang, MD & Whittier Dialysis Center, Whittier, CA \\
\hline Pusadee Suchinda, MD & Carolina Diabetes and Kidney Center, Sumter, SC \\
\hline Mohamed El-Shahawy, MD & Academic Medical Research Institute, Inc., Los Angeles, CA \\
\hline Srinivas Hariachar, MD & Outcomes Research International, Inc., Hudson, FL \\
\hline Melchiore Vernace, MD & Nephrology-Hypertension Specialists, Doylestown, PA \\
\hline Marc Weiner, MD & Hypertension and Kidney Specialists, Lancaster, PA \\
\hline Linda Francisco, MD & Wichita Nephrology Group, Wichita, KS \\
\hline Lawrence Lehrner, MD & Kidney Specialist of Southern Nevada, Las Vegas, NV \\
\hline Moustafa Moustafa, MD & South Carolina Nephrology and Hypertension Center, Inc., Orangeburg, SC \\
\hline Dimtcho Popov, MD & Alabama Clinical Research Institute, Inc., Alexander City, AL \\
\hline Robert Lynn, MD & Nephrology and Hypertension Associates, PC, Bronx, NY \\
\hline Danny Fischer, MD & Kidney and Hypertension Center, Cincinnati, $\mathrm{OH}$ \\
\hline David Ploth, MD & Medical University of South Carolina, Charleston, SC \\
\hline A Kaldun Nossuli, MD & A Kaldun Nossuli, MD, FACP, Bethesda, MD \\
\hline Harold Locay, MD & Discovery Medical Research Group, Inc., Ocala, FL \\
\hline Joseph Aiello, MD & Mountain Kidney and Hypertension Associates, PA, Asheville, NC \\
\hline Cem Harmanci, MD & Lewistown Dialysis Center, Lewistown, PA \\
\hline Khalil Rahman, MD & Khalil Rahman, MD, Lexington, KY \\
\hline Chika Oguagha, MD & The Nephrology Foundation of Brooklyn, Inc., Brooklyn, NY \\
\hline Walid Ghantous, MD & North Suburban Nephrology, Gurnee, IL \\
\hline Lisa Rich, MD & Milwaukee Nephrologists, PC, Milwaukee, WI \\
\hline Theodore Herman, MD & Hypertension and Renal Research Group, Buffalo, NY \\
\hline Hany Rezk, MD & Nephrology Associates, PC, Columbia, TN \\
\hline Albert Matalon, MD & Lower Manhattan Dialysis Clinic, New York, NY \\
\hline Ralph Caselnova, MD & Nassua Nephrology, LLP, Bellmore, NY \\
\hline Wadi Suki, MD & Wadi Suki, MD, Houston, TX \\
\hline Douglas Lanier, MD & South Mississippi Nephrology, Gulfport, MS \\
\hline Matthew Hanna, MD & Milwaukee Nephrologists, SC, Glendale, WI \\
\hline Imtiaz Islam, MD & Platte Valley Medical Group, PC, Kearney, NE \\
\hline
\end{tabular}


Table SI (Continued)

\begin{tabular}{ll}
\hline Investigators & US Institutions \\
\hline Roman Brantley, MD & Nephrology Associates, PC, Birmingham, AL \\
$\begin{array}{l}\text { Paul Dykes, MD } \\
\text { Geoffrey Block, MD }\end{array}$ & Southwest Mississippi Nephrology, PLLC, Brookhaven, MS \\
Irfan Omar, MD & Denver Nephrology Research Division, Denver, CO \\
Roman Mendez, MD & Nephron Associates, PC, Southfield, MI \\
$\begin{array}{l}\text { Donovan Polack, MD } \\
\text { Jeffrey Ryu, MD }\end{array}$ & Alexandria Kidney Center, Alexandria, VA \\
Jesus Navarro, MD & Donovan Polack, MD, St Louis, MO \\
Investigators and sites that screened no patients & Kantor Nephrology Consultants, Las Vegas, NV \\
$\quad$ Kerry Cooper, MD & Genesis Clinical Research, Tampa, FL \\
$\quad$ & \\
Hector Rodriguez, MD, PhD & AKDHC Medical Research Services \\
\hline
\end{tabular}

\section{Publish your work in this journal}

The International Journal of Nephrology and Renovascular Disease is an international, peer-reviewed open-access journal focusing on the pathophysiology of the kidney and vascular supply. Epidemiology, screening, diagnosis, and treatment interventions are covered as well as basic science, biochemical and immunological studies. The journal welcomes original research, clinical studies, reviews \& evaluations, expert opinion and commentary, case reports and extended reports. The manuscript management system is completely online and includes a very quick and fair peerreview system, which is all easy to use. Visit http://www.dovepress.com/ testimonials.php to read real quotes from published authors.

Submit your manuscript here: http://www.dovepress.com/international-journal-of-nephrology-and-renovascular-disease-journal 